Kirja-arvio

\title{
Tuore kokoelma salaliittoteorioista tavoittelee kaikenkattavuutta ja tiedostaa rajansa
}

\author{
Butter, Michael ja Peter Knight (toim.). 2020. Routledge Handbook of \\ Conspiracy Theories. Abingdon \& New York: Routledge. 700 sivua. Arvosteltu \\ versio on e-kirja. https://doi.org/10.4324/9780429452734
}

\section{Toni Saarinen}

$\mathrm{R}$ outledgen käsikirjan kunnianhimoisuus käy ilmi jo nimestä: Routledge Handbook of Conspiracy Theories (jatkossa HOCT) ei sisällä tarkempaa ajallista rajausta tai keskity tiettyyn kulttuurin osa-alueeseen kuten vaikkapa Brillin vuonna 2018 julkaisema Handbook of Conspiracy Theory and Contemporary Religion (jatkossa HOCTACR). Michael Butterin ja Peter Knightin toimittaman teoksen 48 artikkelia pyrkivät kattamaan monta mannerta, ajanjaksoa, ilmiötä ja tieteellistä viitekehystä. Samalla kirja yhdistää ennennäkemättömän monipuolisesti salaliittoteorioita analysoivat alat ja tutkijat ympäri maailmaa.

Poikkitieteellisen käsikirjan viisi osaa on jaettu temaattisesti tai aloittain: ensin käydään läpi määritelmiä ja lähestymistapoja,

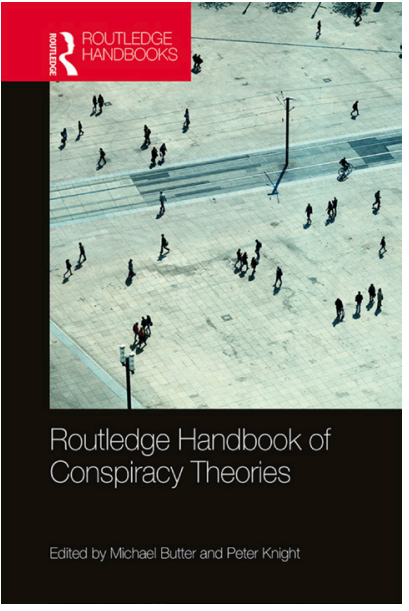
sitten psykologisia tekijöitä, kolmanneksi yhteiskunnallista ulottuvuutta, neljänneksi viestinnän mekaniikkoja ja lopuksi maantieteellistä ja historiallista variaatiota. Psykologiset ja yhteiskuntatieteelliset suuntaukset ovat hallitsevassa asemassa, koska niille omistettujen kokonaisuuksien lisäksi muutkin kirjan osat hyödyntävät niiden metodeja ja tuloksia. Tämä ei ole yllättävää, ovathan nämä alat olleet 2000-luvulla kiinnostuneimpia salaliittoteorioiden muodostumisen edellytyksistä ja olosuhteista - eritoten yksilön ja ympäristön tilastollisista muuttujista. Kirjan toimittajat ovat kuitenkin kulttuurintutkimuksen professoreja: Butter kirjallisuuden ja historian, Knight Pohjois-Amerikan tutkimuksen. He ovat keränneet monipuolisen kattauksen asiantuntijoita myös aloilta, jotka eivät ole vielä täysin ottaneet aihetta omakseen.

HOCT on salaliittoteorioihin vihkimisen ohella hyödyllinen myös yleisperehdytyksenä tiettyjen tutkimussuuntausten metodeihin $(\mathrm{mm}$. sosiaalisen median ja ison datan analyysista Caballero, luku 1.10) ja historiaan nykynäkökulmasta (mm. psykoanalyysista Blanuša 
ja Hristov, 1.5). Määrällisiin tutkimuksiin viittaavien psykologian artikkelien moninaisuus saattaa muodostaa kynnyksen humanistisemmalle lukijalle, mutta näidenkin tulokset ovat oleellisia esimerkiksi demografisten erojen ymmärtämiseksi. Muualta ei myöskään löydy yhtä selkeitä summauksia salaliittoajattelun yhteydestä muun muassa persoonallisuuspiirteisiin ja maailmankuvaan (Lantian, Wood ja Gjoneska, 2.1), motivaatioihin ja tunteisiin (Douglas, Cichocka ja Sutton, 2.3) sekä ryhmien välisiin suhteisiin (Biddlestone, Cichocka, Žeželj ja Bilewicz, 2.6).

Suuntausten monimuotoisuutta humanistivinkkelistä tarkastellessa havaitsee yhden selkeän aukon: uskontotieteellisiä tutkimuksia HOCT:sta löytyy käytännössä vain yksi, vaikka uskomus ja mentaliteetti esiintyvät sanoina jatkuvasti. Syy on epäilemättä se, että Brill julkaisi oman, uskonnollisuutta painottavan salaliittoteorioiden käsikirjansa vain muutamaa vuotta aiemmin. Uskontotieteen kasvava kiinnostus aiheeseen olisi silti voinut tulla alleviivatummaksi teoksessa, joka toivon mukaan vakiintuu lähtöpisteeksi ja keskeiseksi hakemistoksi salaliittoteorioiden tutkimukseen perehtyville.

\section{Kohti ymmärrystä}

Kirjan avaavassa yleisjohdannossa Butter ja Knight tekevät selväksi, millaiseen jatkumoon käsikirja asettuu: salaliittoteorioiden tutkimus on murrosvaiheessa, koska itse käsite "salaliittoteoria" (conspiracy theory) nähdään nykyään enemmän tai vähemmän ongelmallisena. Itsekriittisessä tieteellisessä tutkimuksessa joudutaan myöntämään, että tiede on pitkään lähestynyt aihetta ylimielisesti ja ennakkoluuloisesti. Butter ja Knight alleviivaavat kolmea ongelmaa.

Ensinnäkin salaliittoteorian käsite on voimakkaasti latautunut, ja termiä on säännöllisesti hyödynnetty toisinajattelijoiden marginalisoimiseksi ja patologisoimiseksi. Salaliittoteoreettisuuden on kuitenkin havaittu voivan olla kulttuurista riippumatta melko yleistä yhteiskunnan kaikilla tasoilla, eikä nykyaika ole tässä suhteessa mitenkään poikkeuksellinen vaihe. Lisäksi nykyään tiedostetaan, että varsinkin humanistiset ja sosiaalitieteet jakavat salaliittoteoreettisen ajattelun kanssa monia metodeja ja lähtöoletuksia. Kirjoittajat nostavat esiin Paul Ricoeurin epäilyksen hermeneutiikan, joka ajaa myös salaliittoteoreetikkoja paljastamaan syy-seuraussuhteita pettävän ulkoasun alta. Samansuuntaisen rinnastuksen on tehnyt myös Bruno Latour, joka näkee kriittisen teorian ja sosiaalisen konstruktionismin välineiden siirtyneen salaliittoteoreettisiksi aseiksi (2004, 228-230).

Toiseksi Butter ja Knight muistuttavat, että koska salaliittoja tosiasiassa tapahtuu, sellaiseen uskominen ei voi oletusarvoisesti olla virheellistä ajattelua. Heidän mielestään on tarpeen erottaa yksittäisen historiallisen tapahtuman spekulaatio selityksestä, joka pyrkii kattamaan kaiken mitä maailmassa tapahtuu. Jälkimmäistä kutsun itse myytiksi (Saarinen 2018, 2020; myös Dyrendal, Asprem ja Robertson 2018, 35-41). Tällöin Butter ja Knight esittävät folkloristisesti oleellisen kysymyksen: millainen on mielikuvituksen ja todellisuuden välinen suhde? Kirjoittajat pohtivat Yhdysvaltain hallinnon salaisten ja laittomien operaatioiden paljastumisen vaikutusta kansalaisten kuvittelemien juonien voimistumiseen. Salaliittokulttuuri ammentaa uutisoiduista paljastuksista, mutta näiden historiallisten, "todennettujen" salaliittojen taustalla ovat yleensä olleet valtionjohtajat, jotka itsekin näkevät maailman salaliittoteoreettisesti (Olmsted 2009). Tällaisten palautesilmukoiden vuoksi rajat virallisen ja epävirallisen tiedon välillä hämärtyvät. Lisäksi - kuten kirjan monet artikkelit paljastavat 
- myös viihde ja taide vaikuttavat voimakkaasti maailmankuvan muotoutumiseen. Osuvin vuorovaikutussuhteen kuvaaja olisikin siis mielestäni kolmio, jonka kolmannessa sakarassa sijaitsee populaarikulttuuri.

Kolmanneksi toimittajat problematisoivat salaliittoteorian käsitteen huomioimalla, että nykytutkijat ovat havainneet termin hyvin tuoreeksi: sanalla on ollut merkittävää käyttöarvoa vasta 1970-luvulta alkaen. Ajattelumallit, joita käsitteeseen liitetään, ovat kuitenkin huomattavasti iäkkäämpiä ja mahdollisesti synnynnäisiä mekanismeja ihmisaivoissa. Tämän evoluutiopsykologisen näkemyksen kyseenalaistaminen oikeastaan vain vahvistaa alkuperäistä väitettä: ehkä käsitteessä on vikaa, jos sitä voidaan pitää yhtä ongelmitta sekä universaalina että tietyn ajan ominaispiirteenä. Toisin sanoen salaliittoteoria käsitteenä on moderni keksintö, joka on syntynyt usein poliittisiin tarpeisiin. Tämä pakottaa huomioimaan termin sosiaalisen rakentumisen ja ajassa muuttuvan, häilyvän luonteen sekä kytkeytymisen valta-asetelmiin.

Kirjan johdanto houkuttelee siis tavallaan ymmärtämään, sanan molemmissa merkityksissä, salaliittoteoreettisuutta ja sen eri puolia. Tämä ei tarkoita salaliittoteorioiden hyväksymistä vaan sitä, että niitä lähestytään ilman tunnistettavia vinoumia ja vihamielisyyttä. Ensinnäkin tieteen määritelmät ovat olleet epäselviä, poliittisia ja patologisoivia, mikä on tehnyt salaliittoteorioiden luonteen ja levinneisyyden käsittämisestä vaikeaa. Toiseksi alentuva suhtautuminen tutkimuskohteeseen on sivuuttanut aitoja huolia ja perusteltuja epäluuloja, joista kyseinen maailmankuva versoo (ja muistuttanut siten kolonialistisen Euroopan tieteen suhtautumista alkuperäiskansojen "irrationaalisiin uskomuksiin"). Kulttuurintutkimuksella on hyvät edellytykset lähestyä aihetta sekä vakiintuneita käsitteitä kyseenalaistaen että tutkimuskohteisiin empaattisemmin suhtautuen.

\section{Salaliittokulttuurit kulttuurintutkimuksen keskiössä}

Folkloristiikkaa HOCT:ssa edustaa Tarton yliopiston Anastasiya Astapovan artikkeli (4.1) salaliittoteorioiden suullisesta leviämisestä. Astapova rinnastaa salaliittoteoriat esi- ja varhaismoderneihin huhuihin sekä nykytarinoihin (urban legends) erityisesti niiden kyseenalaistetun totuudellisuuden, ristiriitaisen sisällön ja vaihtelevan muodon vuoksi. Artikkeli tuntuu pitkälti folkloristisen huhututkimuksen eri vaiheiden tiivistelmältä, mutta Astapovan oleellinen väite on se, ettei salaliittoteorioiden kasvu ole vain internetin luoma ilmiö, eikä pelkkä sosiaalisen median tutkimus siksi välttämättä paljasta koko kuvaa niiden kulkeutumisesta. Paikalliset verkostot, joissa tieto leviää tuttujen kesken suullisesti, saattavat tuottaa pitkäkestoisempia vakaumuksia. Niin ikään Tarton yliopistolla työskentelevät semiootikot Mari-Liis Madison ja Andreas Ventsel tutkivat yhdessä professori Massimo Leonen kanssa salaliittoteorioita merkityksen tuottamisen prosesseina (Leone, Madison ja Ventsel, 1.3). Heidän analyysinsa erittelee semioottisia keinoja, joilla salaliittoteorioita käyttäen viestitään pelosta, yhteisöllisyydestä ja me-vastaan-ne-asetelmista. Artikkeli tiivistää hyvin eritoten Madisonin tutkimukset, joissa salaliittoteoriat nähdään Juri Lotmanin ja Boris Uspenskijin määrittelemiä mytologisia (tai metatekstuaalisia) malleja hyödyntävinä ahdistuksen lieventäjinä.

Asbjørn Dyrendalin uskontotieteellinen artikkeli (3.9) tiivistää varhaisemman Brillin käsikirjan, HOCTACR:n päähuomiot. Tärkein näistä on se, kuinka uskonnontutkimuksen viitekehyksessä aihetta voidaan lähestyä käytännössä kolmella tapaa. Salaliittoteorioita voidaan pitää uskontona tai uskonnon kaltaisena ilmiönä; voidaan huomioida, kuinka salaliittoteorioissa 
käsitellään uskontoa; tai voidaan tutkia, kuinka eri uskonnoissa esiintyy salaliittoteorioita. Dyrendal listaa tarkemmin esimerkkejä vain viimeksi mainitusta kategoriasta:Venäjän ortodoksisen kirkon hyökkäyksen Pussy Riot -aktivistiyhtyettä vastaan, rokotekriittisen islamin Nigeriassa sekä uushenkisen salaliittoteoreettisuuden (conspirituality) Norjassa. Vaikka valinnat ovat maantieteellisesti monipuolisia, keskittyminen vain kahteen valtauskontoon ja populaariin uushenkisyyteen tuntuu yksipuoliselta ratkaisulta, ikään kuin maistiaiselta HOCTACR:sta, jonka toimittaja Dyrendal oli. Kaikenkattavuutta tavoitteleva HOCT olisi hyötynyt jokaista lähestymistapaa erikseen avaavasta artikkelista.

Folkloristiikan ja uskontotieteen rajamailla häilyy Annika Rabon kiehtova artikkeli (1.6) salaliittoteorioista okkultistisena kosmologiana. Myös Rabon artikkeli tuntuu esittelyltä hänen oman alansa, antropologian, erään suuntauksen vaiheista. Samalla salaliittoajattelun tulkinta noituutta, saatananpalvontaa ja UFO-abduktioita käsittelevien tutkimusten kautta rakentaa kiinnostavan sillan kysymyksiin tiedosta, toiseudesta ja kätketyn todellisuuden asiantuntijuudesta. Siinä missä Astapova ja Leone et al. yllä huomioivat epävarmuuden salaliittoteorioiden tuottajana, ajatus läpinäkymättömästä (eli paljon salaista ja mutkikasta tietoa sisältävästä) maailmasta epävarmuuden lähtökohtana on hyödyllinen.

Ylempänä mainitsemani populaarikulttuuri salaliittoteoreettisen maailmankuvan välittäjänä on läsnä varsinkin luvuissa 4.2 (McKenzie-McHarg ja Oberhauser) ja 4.3 (Carver), jotka valaisevat hyvin, kuinka jo 1700- ja 1800-lukujen painotekniikka mahdollisti institutionaalisen järjestyksen tehokkaan kyseenalaistamisen. Muuttuvia ja laajalle leviäviä ajatusmalleja ei voi irrottaa keksinnöistä ja kehityksestä, mutta kuten teknologisesta determinismistä varoittavat Andrew McKenzie-McHarg ja Claus Oberhauser huomioivat, teknologia ei ole historiaa ulkopuolelta ohjaava voima - kuten salaliittoteoriat saattaisivat esittää - vaan yhteiskunnallisesti määrittynyttä ja ympäröivän kulttuurin ehdoilla muovautuvaa. Ben Carverin artikkeli 1800luvun brittikirjallisuuden vakoilu- ja dekkarigenreistä havainnollistaa tätä asettamalla nämä lukijan epäluuloa ruokkivat lajityypit historialliseen kontekstiin. Genrejen varhaiset teokset imivät vaikutteita alati yhdistyneemmästä mutta myös epävakaammasta maailmasta, jonka imperialismi ja kansainvälinen poliittinen tilanne olivat aikaansaaneet.

Erityisen kiinnostavaa on sanallisten narratiivien käsittelyn ohella lukea salaliittoteorioiden visuaalisesta välittymisestä (Caumanss ja Önnerfors, 4.5). Kuvallisuuden rooli salaliittoteoreettisten merkitysten viestimisessä on jäänyt miltei huomiotta, kuten kirjoittajatkin toteavat. Meemeillä on kuitenkin valtava rooli esimerkiksi QAnon-liikkeen näkyvyyden kannalta. Samoin salaliittoteorioita propagoivien dokumenttielokuvien analyysi on vielä lapsenkengissään. Michael Butterin artikkeli (4.6) Yhdysvaltain salaliittoteoreettisen elokuvan ja television historiasta jää listamaiseksi fiktiokatsaukseksi, mutta avaa oleellisia käänteitä: salaliittoa juonielementtinä käyttävien tarinoiden määrä kääntyi kasvuun kylmän sodan alussa, ja mitä enemmän maan tiedustelupalveluiden ja presidenttien rikkeitä paljastui, sitä useammin salaliittolaiset olivat valtion sisäisiä toimijoita eivätkä enää ulkopuolisia vihollisia kuten kommunisteja.

Historiantutkijoiden artikkelit kirjassa ovat arvokkaita kulttuurintutkimukselle erityisesti korostaessaan tiettyjen salaliittoteoreettisten symbolien, hahmojen ja tarinakaavojen jatkuvuutta. Esimerkiksi stereotyyppiset mielikuvat juutalaisista ja niiden uusiutuminen keskiajalta lähtien on jäsennelty erinomaisesti Cornel Zwierleinin artikkelissa (5.2), ja Butterin 
(5.10) katsaus Amerikan varhaisten puritaanien maailmankuvaan selittää, miten keskeinen aihio hyvän ja pahan vastainen taistelu on Yhdysvaltain perustamiselle ollut.

\section{Sokeat pisteet esillä}

Käsikirjan monet artikkelit tiedostavat salaliittoteorioiden tutkimuksen kentällä pitkään vallinneen epäkohdan, joka heijastaa laajempaa ongelmaa tiedemaailmassa: valtaosa tuloksista on saatu valkoista, länsimaista keskiluokkaa painottavista kyselytutkimuksista. WEIRD-ihmisiin (western, educated, industrialized, rich and democratic) keskittymisen huomioi eksplisiittisesti Dyrendal (3.9) uskontojen salaliittoteoreettisuutta pohtiessaan, ja kirjan viimeinen osa pyrkiikin korjaamaan virheen omistamalla artikkelit Venäjän (Yablokov, 5.5), Balkanin alueen (Blanuša, 5.6), Turkin (Gürpinar ja Nefes, 5.7), Lähi-Idän (Gray, 5.8), Kaakkois-Aasian (Swami, Zahari ja Barron, 5.9) ja Venezuelan (Hooper, 5.11) vastaaville kehityskuluille.

Muitakin rajoituksia tuodaan ansiokkaasti esiin. Varsinkin sosiologisissa artikkeleissa kirjoittajat toivovat laadullisten ja määrällisten menetelmien rohkeampaa yhdistelyä, painottavat säännönmukaisesti lisätutkimusten tarvetta ja tunnustavat suosittujen kyselytutkimusten epäkohdat. Kuten Jason Harambam (3.2) sanoo, kyselytutkimuksissa analyyttiset kategoriat on rakennettu ennalta, mikä saattaa sivuuttaa salaliittoteoreettisesti suuntautuneiden omat luonnehdinnat. Lisäksi sukupuolen ja seksuaalisuuden vaikutusta salaliittoajatteluun on toistaiseksi tutkittu huomattavan vähän. Annika Thiemin artikkeli (3.3) paikkaa tilannetta, mutta kuten Thiem itse sanoo, suurin osa olemassa olevasta tutkimuksesta keskittyy maskuliinisuuteen ja miesten tuottamiin narratiiveihin. Naisten osuus saattaa kuitenkin olla kasvussa uushenkisen conspiritualityn (Ward ja Voas 2011, 105) vaikutusvallan lisääntyessä esimerkiksi muihin salaliittonarratiiveihin helposti yhdistettävän QAnonin rinnalla.

HOCT kertoo kattavasti paitsi keskeisimmistä löydöistä myös tieteen sitkeistä virhekäsityksistä ja nykyisistä aukoista ymmärryksessä. Huomion keskittäminen salaliittoteoreettisuuteen yhteisöllisenä ja kulttuurisena ilmiönä sekä muuttuvana, uskomuksellisia aineksia sisältävänä maailmankuvana avaa uusia ovia esimerkiksi juuri tiedon auktoriteettien ja maailman läpinäkyvyyden pohdintaan (Rabo, 1.6). Itsekriittisyys puolestaan auttaa ymmärtämään, kuinka paljon on vielä tehtävää ennen kuin salaliittoteorioita voidaan selittää sortumatta yleistyksiin ja tutkijan omien vinoumien vahvistamiseen.

\section{Kirjallisuus}

Dyrendal, Asbjørn, Egil Asprem ja David G. Robertson. 2018. "Conspiracy Theories and the Study of Religion(s): What We are Talking about, and Why it is Important." Teoksessa Handbook of Conspiracy Theory and Contemporary Religion, toimittaneet Asbjørn Dyrendal, Egil Asprem ja David G. Robertson, 19-47. Leiden \& Boston: Brill. https://doi. org/10.1163/9789004382022

Latour, Bruno. 2004. "Why has critique run out of steam? From matters of fact to matters of concern." Critical Inquiry 30(2): 225-248. https://doi.org/10.1086/421123

Olmsted, Kathryn S. 2009. Real Enemies: conspiracy theories and American democracy, World War I to 9/11. New York: Oxford University Press. 
Saarinen, Toni. 2018. "Kuinka monesta tehdään yksi: Uuden maailmanjärjestyksen salaliittoteorioiden myyttiset diskurssit." Pro gradu -tutkielma. Helsingin yliopisto. https://helda.helsinki.fi/handle/10138/277513

Saarinen, Toni. 2020. "Salaliittomyytin synkkä maailma. Pinnan ja syvätason vuorovaikutuksesta." Teoksessa Tuolla puolen, siellä jossain. Käsityksiä kuvitelluista maailmoista, toimittaneet Ulla Piela ja Petja Kauppi, 82-98. Helsinki: Suomalaisen Kirjallisuuden Seura.

Ward, Charlotte ja David Voas. 2011. "The Emergence of Conspirituality." Journal of Contemporary Religion 26(1): 103-121. https://doi.org/10.1080/13537903.2011.539846

Filosofian maisteri Toni Saarinen tutkii vuonna 2020 aloittamassaan väitöskirjassa myyttejä, maailmanloppuja ja modernin ajan erityisluonnetta. Hänen tutkimuksessaan merkittävää roolia näyttelevät myös salaliittoteoriat ja populaarikulttuuri. 